\title{
Helminthofauna of ruminants and solipeds in the Center for Breeding Steppe Animals «Orenburg Tarpaniya»
}

\author{
Pavel Khristianovsky, ${ }^{1,2}$, Vladislav Belimenko ${ }^{3}$, Stanislav Platonov ${ }^{2}$, Dmitrij Grudinin ${ }^{2, *}$, \\ and Semyon Malcev ${ }^{1,2}$ \\ ${ }^{1}$ Orenburg State Agrarian University, 460014, Russia, Orenburg, Chelyuskintsev str., 18 \\ ${ }^{2}$ Institute of Steppe of the Ural Branch of the Russian Academy of Sciences - Orenburg Federal \\ Research Center of the Ural Branch of the Russian Academy of Sciences, 46000, Russia, Orenburg, \\ Pioneer str., 11 \\ ${ }^{3}$ Federal State Budget Scientific Institution «Federal Scientific Centre VIEV», 109428, Russia, \\ Moscow, Ryazanskiy prospekt, 24/1
}

\begin{abstract}
During the autumn-winter-spring season of 2016-2017, the Center for Breeding Steppe Animals (Orenburg region) conducted coprological surveys of herbivores. Identified contamination strongylata have yaks and camels at a low infestation intensity. These animals were not dehelmintizated in the autumn period. By spring, the strongylate infestation intensity in camels increased. The kiangs and Przewalski's horses kept here were subjected to autumn dehelmintization. In these animals, helminths were not detected during the entire study period. It is recommended to carry out planned dehelmintization of animals kept in small protected areas.
\end{abstract}

\section{Introduction}

The development of the steppe zone of Russia in the late XIX-XX centuries led to a significant transformation and fragmentation of natural geosystems, a decrease in indicators of biological diversity and environmental sustainability. This was facilitated by mass plowing of steppes, overgrazing of farm animals, soil erosion, expansion of linear communication networks, etc. The development of steppe landscapes were accompanied by defunitely ecosystems. A characteristic feature of defaunization is not only the reduction in the number or destruction of populations of top predators and herbivores in the ecosystem, but also, as a result, the degradation of natural plant communities. The latter process is especially relevant for steppe specially protected natural areas created on the basis of incomplete ecosystems devoid of megafauna. The absence of large-sized plant-feeders results in the accumulation of excessive biomass followed by steppe mesophytization, and as a consequence, the introduction of hydrophilous vegetation, trees and shrubs, or turning into pyrogenic versions. The inviolability of protected steppe territories ensures the

\footnotetext{
* Corresponding author: grudininda@yandex.ru
} 
preservation of red-listed plant species and demonstrates the restoration of the soil fertility function, but does not ensure the restoration of the biota typical for it.

The turn of the XX-XXI centuries was marked for the steppe zone of Russia by the formation of a low-demand fund of farmland in a number of regions. There were areas of abandoned fields and pastures, where steppe vegetation began to recover. There were questions of ecological rehabilitation of these secondary steppes, restoration of natural ecosystems on them, increase of lost fertility, prospects of integration into the sphere of tourism and recreation, etc. [1].

One of the proposed solutions to the complex of the above-mentioned problems, both for protected areas and for low-demand farmland, is ecological rewilding. Rewilding - the latest environmental ideology based on the restoration of highly productive ecosystems characteristic of this region by gradually returning preserved large animals to their original habitat [2]. In Europe, North and South America, Africa, rewilding becomes the main strategy for conservation of endangered animals, increasing biodiversity and environmental services such as soil protection, carbon sequestration, natural water resources management, improvement of aesthetic qualities and recreational appeal [3-7]. Herbivores, as edifiers, have a significant impact on the environment: they qualitatively and quantitatively regulate the species composition of plants and the distribution of seeds, create heterogeneity of the environment, which leads to an increase in biodiversity and, as a result, the stability of the ecosystem [2]. The technology refers to passive methods of environmental change management that use natural trophic, symbiotic, competitive and other interactions of organisms [8]. This principle will make it possible to attribute rewilding to the number of nature-like technologies for restoring the productivity and biodiversity of ecosystems, which can be used to optimize steppe land use.

It is proposed to restore ecosystems by reintroducing extant species of large animals. Extinct species are replaced by the introduction of related species that occupy a similar ecological niche [8-9]. There is a difficult task of adapting animals raised in captivity and having lost their survival skills in the wild or previously living in a different geographical region to new environmental conditions. Careful planning of introduction, acclimatization, release preparation, and tracking of the new population before it becomes sustainable is required. It is also important to control the impact of the introduced population on the ecosystem [10-12].

The success of the introduction of a particular species is due to many factors, including newly created ecological interactions. To predict the future of the introduced population and the results of introduction at the community level, it is necessary to take into account the patterns of interaction of species, possible environmental and biological risks [7]. One of the significant risks that determine the health and viability of displaced populations is the risk of the spread of diseases and parasites. Disease risk analysis should begin at the project planning stage. It should include all information about the biology of the species, the history of infestations in other geographical settings, known pathogens or parasites of closely related species. Since the immune status of the host can determine the pathogenicity of the organism, it is necessary to assess the ability of introduced animals to cope with new pathogenic pathogens and the stresses to which they will be exposed under new environmental conditions. In the situation of movements outside the territory of the release of the species, the risk analysis of the spread of diseases should include a forecast of the possibility of expanding the range over different periods of time. The depth of analysis should correspond to the estimated probability of the presence of any pathogen and the severity of the consequences of its spread. This analysis should be repeated regularly throughout the project implementation period [9-15].

Since 2014, the project «Orenburg Tarpania» has been operating on the territory of the Belyaevsky district of the Orenburg Region. The main objective of the project is ecological 
rehabilitation of steppes, by returning wild ungulates to them, as a method based on naturelike technologies. The project is implemented on the basis of the field research station «Orenburg Tarpania» managed by the Steppe Institute of the Russian Academy of Sciences The steppe site is an elongated fenced rectangular plot with an area of 35 hectares, divided into aviaries for semi-free keeping of animals. To date, four species of animals representing two faunal complexes are bred at the hospital: Central Asian (Przewalski's horse (Equus przewalskii), two-humped camel (Camelus bactrianus)) and Tibetan (kiang (Equus kiang), yak (Bosmutus)). All four species are not native to this area. To analyze the risk of spreading invasive diseases, coprological examinations of animals were carried out.

Objective: to study the nosological composition and seasonal dynamics of helminthiasis of herbivorous animals in the Center for breeding steppe animals «Orenburg Tarpania». In this regard, the following tasks were defined: to conduct a coprological examination of monocoptyls and ruminants in the «Orenburg Tarpania» in the autumn, winter and spring seasons and to develop a system of anti-helminthic measures for animals of this model territory [16-20].

\section{Material and methods of research}

The object of the study was herbivorous animals of various species. During the research period, the «Orenburg Tarpania» contained kiangs (3), Przhevalsky's horses (2), yaks (3), and camels (4).

The material for coprological studies was fecal masses from these animals. Feces were collected in plastic bags and delivered to the parasitological laboratory of the Orel State Agrarian University (OSAU). Here, the material was examined by Fulleborn ovoscopy. For species differentiation of helminths, larvae were cultured for 7-8 days at a temperature of $20-22^{\circ} \mathrm{C}$, followed by larvoscopy according to Berman-Orlov.

\section{Results and discussion}

Coprological examinations in the Orenburg Tarpania were conducted in 2016-2017 in three seasons of the year - autumn, winter and spring.

During the autumn survey, various helminths infestations of animal species were revealed (Table 1).

Thus, hoofed animals «Orenburg Tarpania» helminth infections have not been identified. This is due to the fact that these animals were dehelmintizated in October 2016 by specialists of the Belyaevsky district. Ruminants were not dehelmintizated here, which immediately affected their infestation. In yaks and camels, eggs of nematodes of the suborder Strongylata were found, including eggs of nematodiruses (in camels).

More precisely species composition of helminthes identified by the method of lavascape (Table. 2).

Thus, yaks were diagnosed with hemonchosis, camels have been identified chabertiosis and nematodirosis. There were no clinical signs in the animals, i.e. these helminthiasis in these animals occurred in the form of a carrier.

At the beginning of March 2017, feces from animals of the «Orenburg Tarpania» were re-collected to monitor seasonal changes in infestation (Table 3, 4).

Analysis of Table 3 shows that strongylate eggs were again found in the feces of ruminants of the «Orenburg Tarpania» with an average intensity of invasion (from 3 to 10 eggs in the field of microscope). No helminth eggs were found in the feces of ungulates. 
Table 1. Results of ovoscopy of collected fecal samples from the Center for breeding steppe animals from 14.11.2017.

\begin{tabular}{|c|c|c|c|}
\hline $\begin{array}{c}\text { № } \\
\text { sample }\end{array}$ & $\begin{array}{l}\text { Species, gender, } \\
\text { age of the animal }\end{array}$ & Result & Amount \\
\hline 1 & Kiang, male, adult & Negative & - \\
\hline 2 & The Przewalski's Horse, female, adult & Negative & - \\
\hline 3 & The Przewalski's Horse, female, 6 months old & Negative & - \\
\hline 4 & Kiang, female, adult & Negative & - \\
\hline 5 & Kiang, female, 6 months & Negative & - \\
\hline 6 & $\begin{array}{l}\text { Yaks, adults, } \\
\text { bull and } 2 \text { cows }\end{array}$ & Strongylate eggs & $\begin{array}{l}\text { Up to } 2 \text { in field of } \\
\text { microscope }\end{array}$ \\
\hline 7 & $\begin{array}{l}\text { Camels, adults, } \\
\text { male and two females }\end{array}$ & Strongylate eggs & $\begin{array}{c}\text { Up to } 3 \text { in field of } \\
\text { microscope }\end{array}$ \\
\hline 8 & & Strongylate eggs & $\begin{array}{c}\text { Up to } 5 \text { in field of } \\
\text { microscope }\end{array}$ \\
\hline 9 & Camel, female, 1 year & $\begin{array}{l}\text { Strongylate eggs } \\
\text { Nematodirus eggs }\end{array}$ & $\begin{array}{l}\text { Up to } 3 \text { in field of } \\
\text { microscope }\end{array}$ \\
\hline
\end{tabular}

Table 2. Results of larvoscopy of collected samples of feces of ruminants «Orenburg Tarpania» from 22.11.2016.

\begin{tabular}{|c|c|c|}
\hline № sample & Animal species & Result \\
\hline 1 & Yaks (3) & Larvae Haemonchus contortus \\
\hline 2 & Adult camels & Larvae Chabertia ovina \\
\hline 3 & & Larvae Chabertia ovina \\
\cline { 3 - 3 } & & Larvae Chabertia ovina, Nematodirus sp. \\
\hline 4 & Young camel & \\
\hline
\end{tabular}

Table 3. Results Results of ovoscopy of collected fecal samples from «Orenburg Tarpania» from 6.03.2017.

\begin{tabular}{|c|c|c|c|}
\hline $\begin{array}{c}\text { № } \\
\text { sample }\end{array}$ & Animal species & Result & Amount \\
\hline 1 & Yak (3) & Strongylate eggs & $\begin{array}{c}\text { Up to 5 in field of } \\
\text { microscope }\end{array}$ \\
\hline 2 & The Przewalski's Horse (2) & Negative & - \\
\hline 3 & Kiang (2) & Negative & - \\
\hline 4 & Young camel - 1,5 month & Strongylate eggs & $\begin{array}{c}\text { Up to } 3 \text { in field of } \\
\text { microscope }\end{array}$ \\
\hline 5 & Adult camels (3) & Strongylate eggs & $\begin{array}{c}\text { Up to } 10 \text { in field of } \\
\text { microscope }\end{array}$ \\
\hline
\end{tabular}

Table 4. Results of larvoscopy of collected fecal samples from «Orenburg Tarpania» from 12.03.2017.

\begin{tabular}{|c|c|l|}
\hline $\begin{array}{c}\text { № } \\
\text { sample }\end{array}$ & Animal species & Result \\
\hline 1 & Yak (3) & Larvae Haemonchus contortus and Nematodirus sp. \\
\hline
\end{tabular}




\begin{tabular}{|c|c|c|}
\hline & & Negative \\
\hline 2 & The Przewalski's Horse (2) & Negative \\
\hline 3 & Kiang (2) & Chabertia ovina and Nematodirus sp. \\
\hline 4 & Young camel, 1.5 months & Chabertia ovina and Nematodirus $s p$. \\
\hline 5 & Adult camels (3) & \\
\hline
\end{tabular}

Table 4 shows that all ruminants of the «Orenburg Tarpania» are parasitized by strongylates of the genus Nematodirus, pathogens of nematodyrosis. In addition, yaks identified the causative agent of hemonchosis, and camels - the causative agent of chabertiosis. These three diseases are in strongylatosis complex of ruminants and are very common.

The final accounting of the seasonal dynamics of helminthiasis of animals of the Orenburg Tarpania was carried out in May 2017 by examining collected fecal samples (Table 5).

Table 5. Results of ovoscopy of collected fecal samples from the Center for breeding steppe animals from 14.11.2017.

\begin{tabular}{|c|c|c|c|}
\hline $\begin{array}{c}\text { № } \\
\text { sample }\end{array}$ & Animal species & Result & Amount \\
\hline 1 & Yak (3) & Negative & - \\
\hline 2 & The Przewalski's Horse (2) & Negative & - \\
\hline 3 & Kiang, female (2) & Negative & - \\
\hline 4 & Camel, female, 1.5 years & $\begin{array}{c}\text { Strongylate } \\
\text { eggs }\end{array}$ & Up to 3 in field of microscope \\
\hline 5 & Camel, female, adult (2) & $\begin{array}{c}\text { Strongylate } \\
\text { eggs }\end{array}$ & Single once in field of microscope \\
\hline 6 & Camel, male, adult & $\begin{array}{c}\text { Strongylate } \\
\text { eggs }\end{array}$ & Up to 50 in field of microscope \\
\hline
\end{tabular}

It follows from the table that no helminthiasis was detected in kiangs and Przewalski's horses here. In yaks, helminth eggs were also not detected, in adult camels, strongylatosis was detected with a low intensity of invasion. This corresponds to the usual seasonal dynamics of strongylatosis in ruminants. In the spring, it is minimal, and many animals are free of helminths, as the life of pathogens ends.

However, a high degree of strongylate infestation was found in the young camel and, especially, in the adult camel. For a larvoscopy 22.05.2017 was discovered chaberties larvae.

During the period of collecting feces, the camel was marked by lethargy, it lay more. According to the staff, he periodically had diarrhea. Thus, the male camel was found to have chabertosis with clinical signs. The camel obvious clinical signs are not observed, but the infestation intensity of chaberties is also high.

It is possible that the male camel was initially highly infected with chabertia, but the autumn and winter study failed to obtain an individual fecal sample from it. In winter, apparently, there was a decrease in the resistance of the body in the male camel and the young camel. This resulted in the best chaberties survival in their body, which was identified in individual ovoscope. The camel also showed clinical signs.

Thus, in the steppe hospital «Orenburg Tarpania», when keeping wild animals in a small limited area, there is an accumulation of invasive origin in the external environment, which causes infection of ruminants with helminths.

In kiangs and Przewalski's horses, after the autumn dehelmintization, no helminths were detected during the entire period of the study. Yaks and camels were not dehelmintizated. 
Nematodes of the suborder Strongylata were found in these animals. This confirms the need to carry out planned dehelmintization of wild animals when keeping them in small model objects.

\section{Conclusions}

1. In the Center of breeding of steppe animals «Orenburg Tarpania», no helminths were detected in ungulates.

2. In ruminants, nematodes of the suborder Strongylata of the genera Haemonchus, Nematodirus, and Chabertia were detected with a low infestation intensity. Helminthiasis occurred in the form of carrier.

3. Infection with strongylates in yaks and adult camels decreased by spring, which corresponds to the usual seasonal dynamics of strongylatosis in ruminants.

4. By spring, the intensity of strongylate infestation in the young camel and adult male camel increased, apparently due to a decrease in the body's resistance. The male also showed clinical signs.

5. In general, helminth infestation was registered in animals of those species that were not dehelmintizated in autumn.

\section{Results and discussion Recommendations}

1. Conduct continuous helminthological monitoring in protected areas.

2. In order to prevent the pastures invasion and helminths infestation of animals, we recommend that in small protected areas, planned dehelmintization of herbivores of all species with feed anthelmintics should be carried out according to the doses established for domestic animals of similar species.

The work is done on the basis of Steppe scientific hospital Institute of steppe, Ural branch of the Russian Academy of Sciences «Orenburg Tarpania» in the framework of research work «Problems of steppe nature management in the context of modern challenges: optimizing the interaction of natural and socio-economic systems» (GR № AAAA-A21121011190016-1).

\section{References}

1. A. A. Chibilev, S. V. Levykin, A. A. Chibilev, G. V. Kazachkov, The problem of lack of demand for land in the steppe zone: classification and typology, assessment of development prospects. Bulletin of the Orenburg Scientific Center of the Ural Branch of the Russian Academy of Sciences, 4, 1-12 (2012)

2. A. I. Kozorez, Pleystocen Park in Belarus, Lesnoe i ohotnich'e hozyajstvo, 10, 42-47 (2014)

3. L. Navarro, H. Pereira, Rewilding Abandoned Landscapes in Europe. In: Pereira H., Navarro L. (eds) Rewilding European Landscapes. Springer, Cham. https://doi.org/10.1007/978-3-319-12039-3_1 (2015)

4. L. Li, D. T. Tietze, A. Fritz, M. Bürgi, I. Storch, Rewilding cultural landscape potentially puts both avian diversity and endemism at risk: A Tibetan Plateau case study, Biological Conservation, 22, 75-86 (2018)

5. M. Root-Bernstein, M. Galetti, R.J. Ladle. Rewilding South America: Ten key questions, Perspectives in Ecology and Conservation, 15, 271-281 (2017) 
6. P. A. Lindsey, G. Chapron, L. S. Petracca, D. Burnham, A. Dickman, Relative efforts of countries to conserve world's megafauna, Global Ecology and Conservation, 10, 243-252 (2017)

7. C. J. Donlan, J. Berger, C. Bock, J. Bock, D. A. Burney, J. Estes, D. Foreman, P. Martin, G. Roemer, F. A. Smith, M. Soule, H. W. Greene, Pleistocene Rewilding: An Optimistic Agenda for Twenty-First Century Conservation, The American Naturalist, 168(5), 660-681 (2006)

8. M. Yu. Vonselev, D. A. Podoshvelev, Reviling of Belarusian natural landscapes: reintroduction of large herbivores, Proceedings of BSTU. Series 1: Forestry, nature management and processing of renewable resources, 2, 128-132 (2018)

9. IUCN/SSC. Guidelines for Reintroductions and Other Conservation Translocations. Version 1.0. Gland, Switzerland: IUCN Species Survival Commission, 57 (2013)

10. K. K. Baytursinov, Factors of formation of the common helminth fauna of wild and domestic ungulates in Kazakhstan, Russian journal of Parasitology, 4, 5-12 (2008)

11. Ya. V. Govorka, Helminths of wild ungulates of Eastern Europe, 85 (Moscow, Aquarium, 1988)

12. L. M. Kokolova, L. Yu. Gavrileva, Z. K. Ivanova, S. M. Stepanova, Helminthiasis of horses of herd keeping in the Republic of Sakha (Yakutia), Theory and practice of animal parasitic diseases, 15, 116-119 (2014)

13. L. P. Maklakova, Experience in the development of methods for predicting and preventing helminthiasis of wild ungulates // Theory and practice of animal parasitic diseases, 13, 233-236 (2012)

14. A. B. Muromtsev, Parasitocenosis of domestic and wild ruminants in the Kaliningrad region, Russian journal of Parasitology, 1, 9-13 (2014)

15. A. K. Oshkhunov, A. A. Didanova, A. B. Fiapsheva, Ecological and faunal characteristics of yak helminthiases in the conditions of the Kabardino-Balkarian Republic, Izvestiya OGAU, 1(39), 234-236 (2013)

16. V. E. Pasechnik, Parasitosis of rare and endangered species of artiodactyls in a zoo and circus, Theory and practice of parasitic diseases in animals, 11, 348-351 (2010)

17. A. N. Pelgunov, L. P. Maklakova, Parasitological aspects associated with the acclimatization and introduction of wild ungulates, Russian Journal of Parasitology, 3 67-75 (2013)

18. N. B. Romashova, O. N. Shchaveleva, The main helminthiases of wild ungulates in the Voronezh region, Theory and practice of parasitic diseases in animals, 11, 385-388 (2010)

19. T. L. Zharkikh, P. I. Khristianovsky, R. T. Bakirova, V. Yu. Petrov, E. A. Bulgakov, D. E. Khuzhakhmetova, V. V. Belimenko, S. A. Platonov, Dynamics of intestinal parasite infection in Przewalski's horses reintroduced to pre-urals steppe, Orenburg state nature reserve (Russia) Nature Conservation Research, 4(2), 23-30 DOI: 10.24189/ncr.2019.027 (2019)

20. A. M. Gulyukin, V. V. Belimenko, A. A. Shabeykin, A. E. Droshnev, A. I. Laishevtsev Epizootogical geo-information systems IOP Conference Series: Earth and Environmental Science, 421, 042013 DOI: 10.1088/1755-1315/421/4/042013. (2020) 